Legal

\title{
Parenthood should be regarded as a right
}

\section{J Boivin, G Pennings}

$\mathrm{T}$ he experience of parenthood is considered to be central to individual identity and to the life plan of most people in most societies. There are many reasons for wanting children: to give and receive love, as an expression of the couple's unity, to give meaning or add value to one's life, for the enjoyment or pleasure of children, to carry on the family name, to be like other friends, to give in to family pressure, to pass on one's genes to the next generation, or even for the material benefits that children can bring, for example for help in old age or governmental assistance. ${ }^{1}$ Although some motives are more common than others and some are perceived as morally better than others, there is consensus that when it comes to having children people have the liberty to choose when, whether, and how many children to have. This right to found a family is considered to be of such importance that it is recognised as a basic human right (Article 16 of the United Nations Universal Declaration of Human Rights; Article 12 of the Human Rights Act).

\section{LIBERTY RIGHTS}

In general, rights are claims to protect a person's interests. Parenthood as a negative or liberty right implies that other persons or the state should not interfere with a person's choice to have or not have children. ${ }^{2}$ People who would limit procreative choice have the burden of showing that the reproductive actions at issue would create substantial harm if followed through.

Rights may also entail obligations. A right to parenthood simultaneously creates a duty to care for the children and a responsibility for their wellbeing. Although some people would like more emphasis on parental responsibilities than on parental rights, this shift would not help decision making regarding reproduction. The framework of rights in the context of reproduction does not put parents against children. On the contrary, as in the discussions regarding maternal-fetal conflicts, maternal decisions are usually to the benefit of the potential child. People should refrain from having children when there is a high risk that the future child will be seriously harmed, either by genetic or socioeconomic causes. However, we are still a large step from promoting coercion or forced intervention in coital reproduction. There is a consensus that such intervention would be disproportional: the benefits (in terms of number of children and harm prevented) would not outweigh the massive violation of privacy and respect for bodily integrity required to justify restrictions on natural reproduction. ${ }^{2}$ This perspective changes radically when people need medical assistance for reproduction, as will be shown.

\section{WELFARE RIGHTS}

More problematic is the notion of parenthood as a positive or welfare right. Positive rights are claims people can make on other people or the state for assistance in the fulfilment of their interests. Most of the time, a claim becomes a positive right when society recognises that claim as a basic need (and not merely as a wish), is necessary for the wellbeing of a person. Whether the desire to have a child is a fundamental need is still open for discussion. In some societies, infertility treatment is included as part of the essential healthcare package to which every citizen has access, whereas in other countries, treatment is not subsidised. Thus the question becomes whether (a) other persons (like medical personnel) and/ or (b) the state are under an obligation to ensure that a person can exercise that right.

\section{Physician collaboration and complicity}

When people are infertile, the nature of the whole family building context changes due to the necessary participation of third parties - that is, medical personnel. These people collaborate in the parental project of the intended parents and as such become partly responsible for the welfare of the children that results from this collaboration. ${ }^{3}$ As a consequence, they have an independent right to determine whether or not they can justify their collaboration in the parental project of the individuals concerned. A blind acceptance of patient autonomy and an absolute interpretation of the non-directivity rule disregards the active participation of the physicians and their ensuing responsibility. ${ }^{3}$ Given the importance of the realisation of parenthood within a person's life plan, it can be argued that physicians have a prima facie obligation to help and should only refuse collaboration when there are real and strong indications that the offspring will be harmed.

\section{State funding}

The most obvious implication of the recognition of parenthood as a positive right would be the state's obligation to provide infertility treatment to its citizens for free. However, given the scarcity of healthcare resources, completely free treatment is unrealistic and probably unacceptable. A limitation on the societal contribution is necessary because otherwise the healthcare budget would quickly usurp the total budget at the expense of other important social values (for example, education) and because the community cannot be expected to participate so extensively in the realisation of the personal desires of individual members. Nevertheless, depending on the value attached to parenthood, steps could be taken by the state to ensure access to infertility treatment without excessive burdens. In the last ten years, a shift can be noticed in society's attitude towards infertile people. A growing number of countries have started systems of state funding. Belgium, France, the Netherlands, and recently the UK reimburse the costs of one or more in vitro fertilisation (IVF) cycles (see, for example, recommendations of the National Institute of Clinical Excellence for IVF). Such (admittedly restricted) systems guarantee greater access and thus partially avoid unjust discrimination on the basis of financial means.

\section{CONSISTENCY AND NON- DISCRIMINATION}

Even if no positive right to medical assistance for infertility is recognised and there is no moral obligation for society to provide assisted reproduction to all those who request it, there is a generally recognised right to not be discriminated against. The principle of justice demands that like cases should be treated alike. When a category of people is excluded from infertility treatment because they possess a certain characteristic (for example, risk for the child, reduced life expectancy, reduced competence) and they are able to show 
that other categories of people who are accepted as patients possess the same characteristics to an equal or even higher degree, the first group may rightly argue to be unjustly discriminated against. Justice considerations would, depending on the attitude towards other groups, generate a positive right to infertility treatment for some groups.

\section{WELFARE OF THE CHILD AND PROCREATIVE LIBERTY}

The most important standard to evaluate the acceptability of procreation is the "welfare of the child" standard. The Code of Practice of the Human Fertilisation and Embryology Authority (HFEA) in the United Kingdom, for instance, stipulates that: "A woman shall not be provided with treatment services unless account has been taken of the welfare of any child who may be born as a result of the treatment ...". While the aim of introducing this standard is laudable and particular attention should be paid to the welfare of the child in the decision, in practice its application is arbitrary and discriminatory because of the difficulty of specifying the content. ${ }^{5}$ Reasons for denying treatment at present reflect more the perceived family ideal than true risk factors for the child. For example, objections have been made on the grounds of the sexual orientation of the parents or their marital status (married, cohabitating, or single), even though neither is negatively associated with child outcomes when confounding factors like education and socioeconomic factors have been taken into account. ${ }^{6}$ Standards like the ideal family are heavily determined by moral and religious background theories. As a consequence, such standards cannot serve for policy decision making since they cannot be defended against people who hold a different world view.
Second, even when risk factors connected to poor(er) child outcomes have been identified, their predictive utility has typically been low because others factors in the child's upbringing (for example, sympathetic grandparents, temperament) can mitigate against the negative effects of the purported risk factor. ${ }^{6}$

A survey of American fertility clinics showed that the main reasons for denying treatment were active substance abuse, ongoing physical abuse, severe marital strife, severe mental impairment, and the presence of a severe personality disorder. ${ }^{7}$ Although consensus probably exists on the undesirability of these particular characteristics, more controversial criteria are also used to limit access to treatment (for example, maternal age, weight). ${ }^{8}$ The limitations imposed on infertile people seeking treatment illustrate well how uninformed external controls can be. In order to avoid arbitrary and prejudiced decision making, the criteria should, as much as possible, be based on evidence from empirical studies demonstrating their importance to child and family outcomes.

\section{CONCLUSIONS}

There is little doubt that procreation as a negative right should be protected. Only in rare circumstances will active intervention to prevent natural reproduction be justified. Procreation as a positive right is more contentious. In general, affluent western societies seem to move in the direction of limited state funding of infertility treatment. As for all other healthcare interventions, this decision is a matter of public debate. Equal access to infertility treatment, apart from the financial aspect just mentioned, should however be guaranteed on the basis of the principle of justice. Whenever certain categories of persons are denied access to treatment, a reason should be given and these reasons should be consistently applied to all relevant similar cases. The selective use of arguments against some groups and not others shows prejudice and discrimination.

\section{ACKNOWLEDGEMENTS}

This article is based on contributions to Straw Poll, BBC4, September 2004, TestBed Productions.

Arch Dis Child 2005;90:784-785.

doi: 10.1136/adc.2004.064485

.............................

Authors' affiliations

J Boivin, School of Psychology, Cardiff

University, UK; boivin@cardiff.ac.uk

G Pennings, Centre for Environmental

Philosophy and Bioethics, Department of

Philosophy, Ghent University, Belgium;

Guido.Pennings@UGent.be

Correspondence to: $\mathrm{Dr} J$ Boivin, School of Psychology, Cardiff University, Tower Building, Park Place, Cardiff CF10 3AT, Wales, UK; boivin@cardiff.ac.uk

Competing interests: none declared

\section{REFERENCES}

1 Langdridge D. Problems of indeterminacy and deontology. Human Reprod 2000;15:502-4.

2 Robertson JA. Children of choice: freedom and the new reproductive technologies. Princeton, NJ: Princeton University Press, 1994.

3 Pennings G, Bonduelle M, Liebaers I. Decisional authority and moral responsibility of patients and clinicians in the context of preimplantation genetic diagnosis. Reprod BioMedicine Online 2003;7:509-13.

4 Human Fertilisation and Embryology Authority Code of practice, 6th edn. London: HFEA, 2003.

5 Blyth E, Cameron C. The welfare of the child: an emerging issue in the regulation of assisted conception. Human Reprod 1998;13:2339-42.

6 Golombok S. New families, old values: considerations regarding the welfare of the child. Human Reprod 1998;13:2342-7.

7 Leiblum SR, Williams E. Screening in and out of the new reproductive options: who decides and why. J Psychosom Obstet Gynecol 1993; 14:37-44.

8 Clark AM, Ledger W, Galletley C, et al. Weight loss results in significant improvement in pregnancy and ovulation rates in anovulatory obese women. Human Reprod $1995 ; 10: 2705-12$ 